\title{
REDD+ as a Public Policy Dilemma: Understanding Conflict and Cooperation in the Design of Conservation Incentives
}

\author{
Hugo Rosa da Conceição ${ }^{1, *}$, Jan Börner ${ }^{1,2}$ and Sven Wunder ${ }^{3,4}$ \\ 1 Center for Development Research, University of Bonn, Genscherallee 3, 53113 Bonn, Germany; \\ jborner@uni-bonn.de \\ 2 Institute for Food and Resource Economics, University of Bonn, Nußallee 21, 53115 Bonn, Germany \\ 3 European Forest Institute, St. Antoni M. Claret 167, 08025 Barcelona, Spain; s.wunder@cgiar.org \\ 4 Center for International Forestry Research, c/o CIP, Av La Molina 1895, Lima 12, Peru \\ * Correspondence: hugorosa@uni-bonn.de; Tel.: +49-228-73-1816
}

Received: 24 September 2018; Accepted: 1 November 2018; Published: 20 November 2018

\begin{abstract}
Command-and-control policies are often criticized as insufficient to tackle tropical deforestation. Over the past two decades, both academics and policy-makers have promoted incentive-based policies, notably REDD+ (Reduced Emissions from Deforestation and forest Degradation), as attractive alternatives to curb forest loss, while also potentially contributing to the poverty reduction of forest-dwelling populations. Governments have been the driving force behind the largest incentive-based forest conservation programs in Latin America. Many science-based recommendations on how to design effective incentive-based policies have, however, not found much resonance within policy circles. To understand the gap between recommendations and practice, it is important to analyze how these schemes are designed towards achieving environmental and non-environmental outcomes. To this end, we analyzed the comprehensive history of governance dynamics behind two government-led incentive schemes in Ecuador and Peru. We found that electoral interests and bureaucratic politics exerted pressure on policy design teams, which eventually traded off long-term societal efficiency concerns against short-term administrative goals. Priority was often given to non-environmental concerns, due to perceptions of political feasibility, the influence of non-environmental government agencies, and beliefs in particular government roles or public response. These findings are especially relevant for scholars studying the design, implementation and impacts of incentive-based conservation policies, and for practitioners aiming to enhance policy efficiency.
\end{abstract}

Keywords: environmental governance; forest conservation; climate change mitigation; public policies; Amazon

\section{Introduction}

Despite the sluggish progress in international climate policy, Reduced Emissions from Deforestation and forest Degradation (REDD+) has become an important international source of funding for forest conservation since the mid-2000s. REDD+ was conceived as a means to harness the allegedly high potential for cost-effective emissions reductions in the forestry sector [1]. As international negotiations went on, countries with forest reserves prepared to receive international transfers for REDD+ implementation.

Incentive-based policies, such as Payments for Environmental Services (PES), were frequently proposed mechanisms to implement REDD+ on the ground [1]. Many PES initiatives were born 
over the last couple of decades, often preceding official decisions at the United Nations Framework Convention on Climate Change (UNFCCC) on REDD+. Existing PES schemes can thus provide lessons to inform the implementation of REDD+ on the ground [2,3].

Governments were often the driving force behind large REDD+ and PES programs [4]. Arguably, due to economies of scale and the possibilities for integration with other sectoral policies, governments are bound to be at the forefront of adopting PES as a large-scale forest conservation tool. Early PES research, however, suggested that government-led PES schemes tend to be less cost-effective than private PES initiatives [5]. Emerging impact evaluation studies confirmed this conjecture, showing that the effectiveness of selected schemes in reducing deforestation has been low [6].

One of the reasons singled out for the low effectiveness of government-led PES is the existence of "major political-economy obstacles" [7] (p. 11) and a "need to accommodate political pressures" [8] (p. 260). Early PES research mostly focused on the technical aspects of designing payments to provide additional environmental services cost-effectively. In recent years, however, a growing body of literature has investigated the complexities of REDD+ and PES policy-making processes, beyond technical aspects. This research focused on the political contexts and discourses related to REDD+ in several countries [9-16], multi-level and polycentric governance issues in REDD+ [17-20], the institutionalization processes of REDD+'s technical aspects such as monitoring and benefit-sharing [21,22], and national case studies on the governance of REDD+ and PES design and implementation [23-28]. This paper seeks to add to this body of literature, accounting in detail for how political processes can shape and transform the design of incentive-based environmental policies.

In a previous article, we [29] analyzed the factors explaining the political dynamics of the adoption of three incentive-based forest conservation programs, the National Program of Forest Conservation for the Mitigation of Climate Change-Programa Bosques-in Peru, the Socio Bosque program-in Ecuador, and the System of Incentives for Environmental Services-SISA-in the state of Acre, Brazil.

Here, we revisit the Programa Bosques and Socio Bosque programs to zoom in on their policy-design processes. We show why and how context-specific political and bureaucratic constraints affected their design, focusing especially on how those constraints led to deviations from efficiency-oriented recommendations in the literature. The two programs were chosen for being both well-known and comparable examples of large-scale PES programs with clear potential for REDD+.

Section 2 presents the conceptual framework used in our analysis. Section 3 describes the history and analyzes the processes that led to the design features of the programs. Section 4 concludes the paper, discussing how the findings are relevant for forest conservation and REDD+ policies. The Supplementary materials provide a factual description of the programs, supporting the understanding of Sections 3 and 4.

\section{Conceptual Framework}

Some articles have utilized institutional frameworks for analyzing PES schemes [30,31], but few have explicitly drawn insights from public policy theories focusing on the motivations of governments [24,32]. In this section, we present a conceptual framework for our two case studies that is derived from different public policy theories. Drawing eclectically on various theories of policy science, our framework does, in Ostrom's words, "provide the most general list of variables that should be used to analyze institutional arrangements" [33] (p. 26).

Policy design is more than a technical exercise of matching appropriate responses to given problems. It is a complex and eventually ambiguous product of interactions and interdependencies occurring, as posed by Howlett [34], at three levels of decision making (see Figure 1). At an abstract level, we label "overarching preferences" (by Howlett, called "macro-level") the general statements of "government aims and ambitions in a specific policy area" and the "long-term preferences of government in terms of organizational devices to be used in addressing policy aims" (p. 75). At the level of "operational policy objectives" (Howlett's "meso-level"), we observe "the specific types of 
governing instruments to be used to address program level objectives" (ibid). In this article, however, our focus is on "specific, on-the-ground micro requirements to attain policy objectives the settings of policy tools required to attain policy targets." (ibid). Choices at this level of "specific design decisions" ("micro-level") will determine the details of how a policy instrument will ultimately be shaped. That does not mean we ignore the importance of long-term policy preferences, but that we seek to analyze policy processes that occurred in a shorter time span. Hence, we interpret long-standing policy preferences (e.g., an marked focus on social policy in Ecuador) as a given policy context in which decisions are made. Figure 1 illustrates the framework and Table 1 describes its elements.

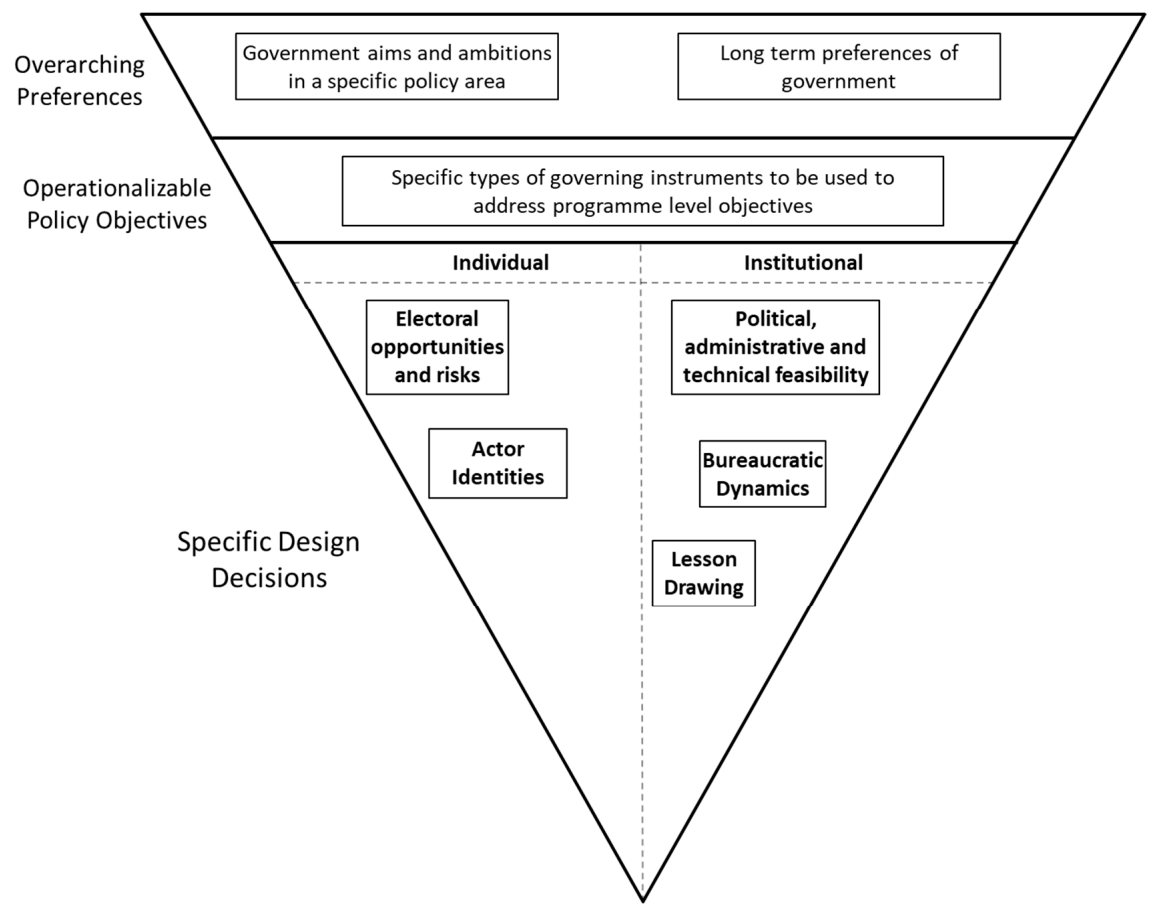

Figure 1. The conceptual framework. Source: elaborated by the authors.

Table 1. The concepts of the policy theory applied.

\begin{tabular}{|c|c|c|c|}
\hline $\begin{array}{l}\text { Explanatory } \\
\text { Element }\end{array}$ & Summary Description & Theoretical Tradition & References \\
\hline $\begin{array}{l}\text { Electoral } \\
\text { opportunities } \\
\text { and risks }\end{array}$ & $\begin{array}{l}\text { Politicians try to maximize power and rank short-term interests } \\
\text { over long-term consequences. Policy design aims at maximizing } \\
\text { electoral votes. Bureaucrats seek to maximize agency budgets, } \\
\text { career advancement, and self-favored policies. }\end{array}$ & Public Choice Theories & [35-37] \\
\hline Actor identities & $\begin{array}{l}\text { Expands the actors' motivations from pure utility maximization } \\
\text { towards their idiosyncratic characteristics, e.g., education, } \\
\text { commitment to service, expertise, tenacity, and political skills. }\end{array}$ & $\begin{array}{l}\text { Multiple Streams } \\
\text { Framework (Policy } \\
\text { Entrepreneurs), } \\
\text { Street Level } \\
\text { Bureaucracy }\end{array}$ & {$[38,39]$} \\
\hline $\begin{array}{l}\text { Political, } \\
\text { administrative, and } \\
\text { technical feasibility }\end{array}$ & $\begin{array}{l}\text { The institutional context in which decisions are made. Political } \\
\text { feasibility factored into design decisions as a guide to action, or as } \\
\text { an explanation for previous behavior. Administrations prefer } \\
\text { policies that are less costly to design and run, especially in } \\
\text { low-priority sectors with limited resources and personnel. }\end{array}$ & Institutionalism & {$[34,40,41]$} \\
\hline $\begin{array}{l}\text { Bureaucratic } \\
\text { dynamics }\end{array}$ & $\begin{array}{l}\text { Relations between government agencies involved in a policy area. } \\
\text { Coordination capacity, internal turf battles, and jockeying for } \\
\text { influence will often influence the design processes. }\end{array}$ & $\begin{array}{l}\text { Institutionalism, } \\
\text { Organizational Theory }\end{array}$ & {$[42,43]$} \\
\hline Lesson-drawing & $\begin{array}{l}\text { Policymakers will often look at other jurisdictions to draw 'tried } \\
\text { and tested' policy options. Lesson-drawing occurs as a more or } \\
\text { less intact adoption of a program already in effect in another } \\
\text { jurisdiction, as the combination of several policies, or as simple } \\
\text { inspiration/ intellectual stimulus. }\end{array}$ & Institutionalism & {$[44,45]$} \\
\hline
\end{tabular}




\section{The Design of Public PES Schemes: Socio Bosque and Programa Bosques}

This section describes how academic recommendations for cost-efficient PES were considered in the design of each program, and analyzes the underlying decision-making processes. Table 2 summarizes the section. A detailed description of the programs is provided in the Supplementary materials. Our sources of analysis were personal interviews with current and former policymakers who were directly or indirectly involved with program design, and a thorough scrutiny of design documents, as well as triangulated opinions on (and external analyses of) how design decisions were made and implemented.

\subsection{Conditionality, Monitoring, and Baselines}

Conditionality means that payments should only be made if environmental services (ES) are being provided, or a proxy activity clearly linked to the provision of ES is implemented. It is the defining characteristic of PES programs, the one that distinguishes them from more traditional subsidy programs [5,46]. Conditionality is the combination of compliance monitoring ("efforts to detect non-complying participants, typically combining remote-sensing technologies with on-site ground truthing") [46] (p. 146), and sanctioning non-compliance, usually by suspending or withdrawing payments. PES programs should also construct baselines to enable the understanding of what would have happened without the scheme and to gauge additionality.

Socio Bosque's design contains clear conditionalities attached to payments. Program planners emphasized the need for simplicity and clarity of conditionalities, given that long administrative procedures would put off many potential beneficiaries, and due to concerns with administrative capacities in the long term (Appendix A: Interview 5). When the program was created, no country-wide forest monitoring system or forest cover baselines existed. The design teams decided to set up an extensive monitoring system and a baseline study as one of the program's core components (Interview 5), instead of setting up the systems before the beginning of the payments. Specific property/community baselines were developed as a requirement for enrollment so that compliance could be monitored.

Monitoring activities were implemented through the analysis of satellite imagery and field verification of zones which are deemed as being potentially threatened. According to a recent monitoring report (December 2015), 89.92\% of the enrolled area has been analyzed [63]. Also in 2015 , field verification identified $6.6 \%$ of the areas as non-compliant with the program's regulations (ibid). Additionally, a country-wide baseline has been completed and published after the start of the program [64].

The creation and design of Programa Bosques were inspired by the Juntos conditional cash transfer (CCT) program [29], so the inclusion of conditionalities was integral to Programa Bosques (Interview 12). The rationale for the definition of the conditionalities was to ensure that communities would not perceive the incentive as a hand-out, and that they should be easily understandable (Interview 12). The envisaged forest cover monitoring system was not complete at the beginning of the program, as satellite images of enrolled communities were not yet available. The images were later acquired, on a yearly basis, with the support of the German Agency for International Cooperation (GIZ). To monitor compliance, a participatory mapping was made together with the communities, including the definition of the zone to be put under conservation, later to be complemented with satellite images. The first cash transfers were provided upfront, without considering forest cover dynamics. The communities used that money to implement sustainable productive activities (see Section 3.6 below, and the Supplementary materials). By the end of the first year, compliance monitoring was performed: if the communities had complied with all conditionalities, they would be eligible for the second payment—and so on for the following years (personal communication, R. Giudice, 8 April 2018). 
Table 2. The design for cost-efficient PES (Payments for Environmental Services): theoretical recommendations vs. policy choices and their implementation.

\begin{tabular}{|c|c|c|c|c|}
\hline \multicolumn{2}{|c|}{ Main Theoretical Recommendation } & References & Socio Bosque (Ecuador) & Programa Bosque (Peru) \\
\hline \multirow{2}{*}{$\begin{array}{l}\text { Conditionality, Monitoring, } \\
\text { and Sanctions }\end{array}$} & \multirow{2}{*}{$\begin{array}{l}\text { Payments to be conditional on ES provision } \\
\text { (or proxied land uses), and non-compliance } \\
\text { to be sanctioned. Baselines, controls and } \\
\text { monitoring required to evaluate } \\
\text { attributable outcomes. }\end{array}$} & \multirow[b]{2}{*}[7,8,46-51]{} & \multicolumn{2}{|c|}{$\begin{array}{l}\text { Environmental (e.g., maintain forest cover in enrolled areas) and administrative (e.g., accountability reports) } \\
\text { conditions to payments. Baselines and monitoring system to be fully developed during implementation. Eventua } \\
\text { payment suspensions in case of continuous administrative and environmental non-compliance. }\end{array}$} \\
\hline & & & & $\begin{array}{l}\text { Upfront payments were provided without } \\
\text { performance-based monitoring. Subsequent payments } \\
\text { based on conditionality compliance. Sanctions to } \\
\text { non-compliant participants are being applied. }\end{array}$ \\
\hline $\begin{array}{l}\text { Poverty reduction and equity } \\
\quad \text { (incl. participation }{ }^{1} \text { ) }\end{array}$ & $\begin{array}{l}\text { PES schemes should focus primarily on ES } \\
\text { provision. Poverty alleviation can be } \\
\text { a co-benefit. Negotiated, flexible PES } \\
\text { schemes are more equitable. }\end{array}$ & {$[7,46,48,52-54]$} & \multicolumn{2}{|c|}{$\begin{array}{l}\text { Poverty reduction is one of the main stated objectives and a parameter for targeting. The participatory process is } \\
\text { largely absent (top-down design). Voluntary enrollment. }\end{array}$} \\
\hline \multirow[b]{2}{*}{$\begin{array}{l}\text { Spatial targeting in the selection of } \\
\text { ES (environmental services) } \\
\text { providers }\end{array}$} & \multirow[b]{2}{*}{$\begin{array}{l}\text { Schemes should target enrolment of areas } \\
\text { with high ES provision potential and high } \\
\text { risks of ES loss, and low provision costs. }\end{array}$} & \multirow[b]{2}{*}[7,47,48,55-58]{} & \multicolumn{2}{|c|}{ Participants self-select which parts of their land they set aside for conservation. } \\
\hline & & & $\begin{array}{l}\text { Based on the assumed level of the threat, environmental } \\
\text { service, and level of poverty. } \\
\text { Was applied only after there were more enrollment } \\
\text { requests than resources (from 2012). }\end{array}$ & $\begin{array}{l}\text { Region and community targeting. Based on primary } \\
\text { forest area, deforestation rate and poverty incidence rate } \\
\text { and closeness to access alternatives (e.g., roads, cities). } \\
\text { Targeting has not been homogeneously followed by the } \\
\text { program, with some communities not ranked as priority } \\
\text { areas being enrolled }\end{array}$ \\
\hline Payment size and modalities & $\begin{array}{l}\text { Payments should vary according to the } \\
\text { value of ES and their provision costs (i.e. } \\
\text { opportunity costs) to maximize impact for } \\
\text { a given program budget. }\end{array}$ & {$[46,51,59]$} & $\begin{array}{l}\text { Differentiated payments. Based on the enrolled area size } \\
\text { and the type of vegetation and ownership. } \\
\text { The amounts paid to beneficiaries were changed during } \\
\text { the implementation to reflect property/community } \\
\text { sizes and serve as a proxy for opportunity costs. }\end{array}$ & $\begin{array}{l}\text { Undifferentiated payments. Based on the enrolled } \\
\text { area size. }\end{array}$ \\
\hline $\begin{array}{l}\text { Integrated Conservation and } \\
\text { Development Program (ICDP)-type } \\
\text { components }\end{array}$ & $\begin{array}{l}\text { PES have been conceived as alternatives to } \\
\text { ICDPs. Combining PES with development } \\
\text { support can confuse program goals, inflate } \\
\text { costs, and eventually compromise } \\
\text { conservation outcomes. }\end{array}$ & {$[7,48,60-62]$} & \multicolumn{2}{|c|}{$\begin{array}{l}\text { Payments contingent on the development of ICDP-type activities aiming at generating income (not applicable to } \\
\text { individual landowners in Socio Bosque). }\end{array}$} \\
\hline
\end{tabular}

${ }^{1}$ Participation of multiple stakeholders in program design is a prominent theme in PES debate and practice. It is commonly discussed, together with poverty reduction, within the broad theme of "equity". 
Data on conditionality enforcement has not yet been consolidated, but according to our personal communication with program staff, some sanctions for non-compliance have been imposed. Ten communities were evicted from the Program between 2011 and 2014, and a few more were suspended for one year and rejoined in the following year. The main reason for eviction has been the use of cash transfers for reasons not included in the investment plan, which details how beneficiaries are planning to use the money transferred from the program to carry out productive projects expected to improve their welfare. Other reasons were deforestation beyond the allowed threshold $(0.3 \%$ of the area committed for conservation over the 5 years of the conservation agreement [65]) and receiving a fine or sanction from another forestry regulatory office (personal communication, R. Giudice, 8 April 2018).

While conditionalities were swiftly agreed upon in both programs, several contextual factors explain the decision to provide initial upfront payments and only condition-subsequent payments on compliance. Both programs have the dual objective of conserving forests and reducing poverty (see Section 3.2) and intend to achieve those objectives by implementing ICDP-like sustainable productive activities (see Section 3.6). Therefore, upfront payments to initiate those activities are an integral part of the programs' intervention strategies. Additional factors help to explain that design feature. In Ecuador, the idiosyncratic characteristics of President Rafael Correa were relevant, as he pressured for quick government action in various policy areas. From the beginning of his mandate, he was trying to implement fundamental changes in Ecuadorian institutions. One of the core changes observed in the country was the strengthening of the executive power's capacity to formulate public policies, to the detriment of other institutions such as Congress [66,67]. At the base of his political changes was a new constitution, which the president hoped to approve in a referendum. The public debate on the constitution overlapped with the design process of Socio Bosque. The constitutional referendum happened in September 2008 and Socio Bosque officially started in November 2008. To ensure support, Correa intended to demonstrate a commitment to quick and bold action by the government. Therefore, the political context in which the design team worked urged for a quick start of the payments (Interview 5).

In Peru, a similar pressure for quick completion of the design process existed, but the political feasibility and bureaucratic dynamics were more relevant factors. First, the government aimed to mend its relations with indigenous populations, which were strained due to confrontations between police forces and indigenous populations known as Baguazo [29,68]. A dragging design process would delay the beginning of payments, which was understood to be potentially counterproductive to that aim (Interview 21). In addition, the Environment Ministry (MINAM) was a new entity in the government (created in 2008) and sought to demonstrate efficiency to a skeptical Council of Ministers (Interview 24).

\subsection{Poverty Reduction}

PES have been considered attractive to conservation practitioners and policymakers as a possible win-win solution for tackling environmental problems and contributing to poverty alleviation concomitantly [69]. There are, however, often tradeoffs between both objectives [46,51]. From an efficiency perspective, those who should receive payments are the ones who pose a credible (or, at least, credibly projected) threat to the provision of ES [7,47]. For that reason, several researchers note that poor land users, who usually have small plots and few means to seriously threaten themselves and/ or protect their environment against outsiders, will often not be the most efficient providers of ES [48,52]. Programs that target payments to poorer populations risk having higher costs and low environmental additionality. For that reason, many authors have stressed that the PES schemes should not be promoted as poverty reduction tools [48,52,53]. In other words, "poverty alleviation is an important side objective, which can be pursued through timely interventions, but it should never become the primary objective" [7] (p. 22). On the other hand, some authors argue that the existence of interdependencies between effectiveness and equity outcomes [70] can make poverty reduction a necessary condition for ES provision [71]. 
Contrary to most recommendations in the literature on cost-efficient PES, poverty reduction was a central concern in Socio Bosque's design, as it was in its adoption [29]. Several of the design provisions in Socio Bosque aim to benefit poor population segments. The decision to include communities in the program was driven by the goal to provide them with cash transfers [72]. Welfare concerns also guided the definition of a poverty parameter for targeting, and the interest in fostering potential income-generating activities also motivated the inclusion of ICDP-type activities (see below). The program, however, was not able to reach many of the poorest inhabitants of forests because, for legal reasons, it can only enroll participants with formal land titles (Interview 5).

The design process had a limited formal participation of national actors outside of the government [73,74], except for the partnership with Conservation International throughout the design process and informal contacts with some potential beneficiaries, as well as local governments already implementing PES projects (Interview 5). The lack of participation design was justified by the program designers with the voluntary enrollment in the program, allegedly deeming the participation of civil society actors unnecessary (Interview 5). Additionally, the design team understood that a consultation process would hinder the program's quick deployment, as there were pressing requests from the president's office to get the project started quickly ([73], interviews 5, 12).

Poverty reduction concerns were also central to the design of Programa Bosques. Similar to Socio Bosque, they were key factors in design decisions on targeting, payment system definition and, crucially, the introduction of ICDP-type activities (Interview 21, 23). We could not, however, find evidence on the extent to which these design elements were thoroughly discussed by the design team, or if they straightforwardly adopted Socio Bosque's design model. The design process of Programa Bosques also did not count with the wide participation of non-government stakeholders. A few meetings were held with the NGO Inter-Ethnic Association for the Development of the Peruvian Forest (AIDESEP) to discuss some of the initial drafts of the program (Interview 22), but we could not infer how much of AIDESEP's input had been adopted. The design team also reasoned that since participation in the program is voluntary, a thorough participatory process would make the design process unnecessarily time demanding (Interviews 21, 22, 23).

The centrality of poverty reduction concerns in both programs is, perhaps unsurprisingly, the most outstanding deviation from policy recommendations. Improving the living conditions of the poor has been the main overarching declared objective of Latin American governments for many years, and more markedly since the 2000s, with the emergence of leftist-populist governments all over South America [75,76]. Even before those developments, CCT programs started proliferating in Latin America. Studies found that voters tend to reward governments that implement targeted social assistance programs [77-79], at least in the short term [80]. Subsidies for forest conservation can, in addition, also legitimately benefit geographically marginalized rural populations that are otherwise hard to reach for central states.

Additionally, pro-conservation action could be popular with an environmentally conscious electorate. Our respondents agreed that conservation remains a low priority for voters, although there were no consistent studies or opinion polls found on the voters' preferences to back that perception. However, there is a documented increasing trend in environmental movements' activity and in the public environmental awareness in the region [81-83], which may have influenced the adoption of the programs, despite it not being explicitly recognized by respondents. In any case, an increased environmental awareness in the public does not necessarily mean that forest conservation would overtake welfare issues as a priority for voters. Hence, governments should have a political interest in associating conservation and welfare policies. It is fair to say that both programs have been designed with the intention of being perceived as a hybrid of environmental and social policies, with the latter probably being in the driver's seat. 


\subsection{Spatial Targeting in Selecting Participants}

Since funds for PES schemes tend to be limited, it is crucial to carefully determine where interventions will take place and which actors will participate in them. Spatial targeting of PES should consider both benefits and costs in site selection [51], mainly focusing on areas with a high-ES density [46,55], high deforestation risk [55,56], and low costs relative to the service levels [84]. Appropriate targeting is relevant to ensure higher additionality of a PES scheme and its cost-effectiveness [46,55].

Socio Bosque "has not specifically targeted enrollment to generate increased outcomes in prevented deforestation and provision of environmental services" [85] (p. 104) but developed targeting (prioritization) criteria in their operational manual to define who would be enrolled first. The prioritization criteria used are the level of threat, proxies for environmental service provision, and poverty levels [86] (see Supplementary materials for detailed targeting criteria). Prioritization was not intended to be applied from the beginning of the program, but only after there was more demand for participation than the supply of funds available for new enrollments, which happened in 2012 [87].

The targeting process at Programa Bosques is divided into two steps. The first is the selection of which provinces are the priorities for conservation. Three criteria are considered at this stage, (a) the total area of primary forests, (b) deforestation rates, and (c) the poverty incidence rate. The second is the selection of which communities within the previously prioritized Provinces should take priority in participating in the program. The indicators used in this phase are (a) the total area of primary forests, (b) the percentage of conserved primary forests, and (c) the closeness to transport routes [88] (see Supplementary materials for detailed prioritization criteria). The selection of the initial Provinces, at the Valley of the Apurimac and Ene Rivers (VRAE) region, however, did not follow the prioritization criteria and was instead motivated by the government's interest to benefit a region with a history of poverty and political conflict (Interview 21). Furthermore, according to information provided by the GIZ-Peru staff (personal communication, R. Giudice, 8 April 2018), the criteria for prioritization of communities has not been homogenously followed by the program. In 2011, for example, the program prepared a ranking of 102 communities based on the prioritization criteria, with the first 50 being considered a priority for enrollment. In that same year, 27 communities voluntarily applied for enrollment, of which 17 were enrolled by the end of that year. Only 10 of those 17 were among the list of 50, and five were not even ranked within the list of 102 communities.

Targeting is, politically, one of the trickiest aspects of the design of a PES program, as it will ultimately define who participates-and eventually benefits. Consequently, Ecuador and Peru developed targeting schemes for selecting participants, but enrolled participants with a wider range of characteristics. Respondents indicated technical reasons for their selection of targeting strategies. Some of the data for the whole country that were required to implement targeting were lacking. For that reason, the start of program implementation would allegedly have to be delayed for a few months while the programs were urged by higher authorities to deliver payments as soon as possible (Interview 5, 17). There were also concerns about political feasibility and medium-term electoral strategies of the governments. Targeting conservation incentives to maximize cost-effectiveness may generate a perception of unfairness if the targeting criteria discriminated against poor landholders or good forest stewards. A perception of unfairness, justified or not, may jeopardize program acceptance, undermine the government's popularity in the intervention area, and cause rifts among the population. Additionally, the number of enrolled participants and the size of the forest areas under the programs are arguably regarded as the most important early measures of success for the programs since measurements of actual deforestation reductions, additionality, or improvements in incomes of enrolled beneficiaries are, at the time of writing, incipient at best.

\subsection{Selection of Plot-Level Conservation Areas}

Once the participants were selected, their contractual conservation areas also needed to be defined. When landowners self-select those, they will likely choose from the start those that are least 
threatened (remote, inaccessible, steep, etc.), where deforestation risks are minimal. Payments would, thus, make no difference: the so-called adverse selection bias [89] would apply. One PES design recommendation is, therefore, to make conservation agreements for the entire land area of participants, so as to counteract self-selection bias.

In both Ecuador and Peru, however, the participants themselves define what part and share of their land would be enrolled in the programs, whereas deforestation could legally continue on other lands. Respondents argued that the decision to allow communities and individuals to self-define conservation areas was taken to maintain coherence with the voluntary nature of the programs (Interviews 5, 8, 24).

Electoral interests are likely to have also played a role here. A top-down definition of eligible areas could have been erroneously perceived as a violation of land use rights, especially when community conservation agreements were made-a problem also observed with the ejidos in Mexico [90]. The design teams reckoned that, even in a context of voluntary enrollment, a perceived interference in land use decisions would discourage participants from enrolling (Interview 5, 17). In Ecuador, the team was indeed aware of reports of previous activities in which communities felt discouraged to participate when they perceived that their freedom to make land use decisions would be hindered by conservation incentive projects, as described in Profafor and GIZ [91]. Another study [92] that analyzed the factors affecting desire to participate in Socio Bosque, focused on páramos areas. It found that "a fear of land expropriation" was one of the most important factors triggering a lack of desire to participate, together with "insufficient incentive payments to cover opportunity costs" (p. 128). Similar notions were reported in a study of the Ecuadorian Amazon region, where concern with expropriation was also reported, with a "fear that at the end of the 20-year contracts, the forested land would revert to the government. As stated by a male non-participant, 'some neighbors fear Socio Bosque is a trick, a way for the government to take possession of your land'" [93] (p. 7).

\subsection{Payment Differentiation}

The PES literature recommends differentiating payments according to variable ES benefits and costs of ES provisions across participating landowners [51]. For the latter, payments may conveniently be aligned with landowner opportunity costs, if these can be approximated [59]. Payment differentiation is likely to increase the environmental effectiveness of a PES scheme [94] and may also make the distribution of benefits more equitable if differential ES provision costs among participants are used as an equity criterion [46].

Opportunity costs were not calculated for the definition of payment levels in Ecuador. The project team considered that "different levels of incentives depending on the specific location of a landowner would be a cause of intense social debate and would not be politically viable" [72] (p. 535), and that a lengthy process to estimate opportunity costs would reduce the political momentum for program adoption [73]. Opportunity costs and other design parameters were discussed during consultations with international PES experts, including individuals from the Mexican and Costa Rican programs, at an expert meeting held in Hacienda Cusin (Otavalo), just a few weeks prior to the launching of the program. The experts suggested several alternative ways to use opportunity costs for payment differentiation, including a straightforward road zoning proxy system (Interview 13). Representatives of the Costa Rican delegation allegedly argued that the explicit use of opportunity costs could be politically complicated and unnecessary. As a reason, they suggested that such a differentiation is hard to communicate and could lead to complaints about undue favoritism. The Socio Bosque team thus decided not to follow the recommendations provided by the academic specialists (Interview 2) on opportunity costs. There was, consequently, no thorough answer on the definition of the specific payment values used by Socio Bosque. Respondents stated that the design team took into consideration budgetary possibilities and tried to offer the highest possible payment for participants (Interviews 2, 5).

However, since one of us (Wunder) participated as invited PES specialist in the expert meeting to inform the design of Socio Bosque, some triangulation of the interview information is possible here. 
The meeting was held just a few weeks prior to the launching of the program, which was politically timed to occur around the time of the constitutional referendum (see above). In practice, significant design choices such as payment differentiation were, at this stage, no longer possible, nor was strong advice in that direction necessarily desired by the ministerial staff. National experts from Conservation International, closely working with the Ministry on program design, voiced also a clear framework for what was or was not politically feasible at this stage of the process. This caused some friction with some of the international experts, feeling their participation from the outset was being used as a legitimizing procedural tick-off, rather than a genuine technical input into program design-which, in all major respects, had de facto already been predetermined.

Nevertheless, the meeting perhaps raised some awareness among Socio Bosque stakeholders about the importance of opportunity costs, which influenced the future implementation process. The area-based payment differentiation was devised as a proxy for opportunity costs, with the "assumption that opportunity costs decrease when the area increases, since access becomes more difficult in larger areas", but "was also a political decision to maximize the limited budget that was available" [95] (pp. 1173-1174). Likewise, the changes in the payments structure introduced in October 2011 showed at least an implicit recognition of potential efficiency gains from taking opportunity costs into consideration. The program added a differentiation between individual and collective lands, and between páramos and other vegetation types, as well as adding a special category for properties under 20 ha. The new structure increased per-hectare payments for communities and kept original values for individual landowners, except in the under 20ha new category [96,97] (for additional information, see Supplementary materials). Changes were also due to a decrease in the rhythm of new participants signing up, especially in páramos areas [95]. The initial values were loosely based on the incentive values of similar programs implemented in other countries (e.g., Mexico and Costa Rica) and on the budgetary possibilities of the program (Interview 5).

The Programa Bosques did no adopt a differentiated payments structure, although it reportedly drew explicitly on lessons from Socio Bosque. The interviews and program documentation did not yield solid evidence for specific reasons why an undifferentiated payment structure was chosen, or why opportunity costs were not considered. According to the respondents in Peru, the specific amount of the payment was defined largely for the sake of simplicity, with the value of 10 Soles per ha/year being deemed as easy to understand and communicate, and within a realistic budgetary range (Interviews $21,23)$. However, in an exchange with international scientists (including co-author Börner) prior to launching the program, government representatives evoked similar fairness arguments against payment differentiation as in Ecuador.

\subsection{ICDP-Type Components}

PES were conceived as "alternatives to the more indirect pro-poor investments for transforming livelihoods such as ICDPs" [98] (p. 134). ICDPs have been significantly widespread since the 1990s, with the aim of promoting conservation by providing "alternative sources of products, income, or social benefits" [60] (p. 1718). ICDPs, however, have shown a mixed track record, at best, in terms of achieving their proposed conservation objectives and, crucially, provide payments that are not conditional on the objectives set $[60,99]$. Additionally, combining PES with development support can confuse program goals, inflate costs, and eventually compromise conservation outcomes $[7,48,60]$. Nevertheless, the 'PES-positive' literature sees possible benefits for ICDP-like activities, if they are approached creatively, especially by adapting conditionalities [7]. Additionally, some activities that can be promoted under a PES scheme, "for example switching to agroforestry or silvopastoral practices", may "become profitable for the landholder after some years of implementation", inducing "the landholder to adopt the environmentally friendly practice" [51] (p. 149).

Both Socio Bosque and Programa Bosques, however, included ICDP-type components in their design, which they call productive projects or activities (see Supplementary materials). That means that the incentive provided cannot be freely utilized by the communities, but must be invested in 
activities intended to generate income, making the program ultimately a source to finance small-scale, community-led ICDPs. The explanation for the lingering interest in ICDP-type activities is manifold. Program designers believed that the payments should not appear to be handouts, but must become seed funds for the construction of long-term solutions for the communities' socioeconomic issues (Interview 5, 23). From a technical standpoint, the fact that the money is given to a community, with a political/hierarchical structure of their own, tying payments to reportable productive activities was seen as the best way to accountably spread benefits inside the community, counteracting elite capture and misuse. However, the subsequent implementation shows that these expectations were not always met. Early analyses of Socio Bosque show that productive activities have not always ensured transparent and informed decision making in communities [74] and that "some communities are having difficulties distributing the costs and benefits of participation in Socio Bosque fairly" [100] (p. 8), reporting evidence of "intracommunal power imbalances and elite capture" [95] (p. 1180).

In Peru, bureaucratic intra-governmental dynamics also played a role. The ability to demonstrate the investment of payments in productive activities came to be an important asset in negotiations with the Ministry of Economy and Finance (MEF), which was much more willing to approve budgets to a program with a stimulus to economic activity than a transfer for 'not doing something' (i.e., avoiding deforestation) (Interview 24). This led the design team to look to Socio Bosque's concept of investment plans attached to the payments (see Supplementary materials). The persistence of ICDP-type components, therefore, shows that the idealized view of PES as a poverty-environment "win-win" solution [69] was relevant for the design of the programs, especially to ensure the support of non-environmental agencies.

\section{Conclusions}

As we have seen, the centrality of development, welfare and poverty reduction considerations aimed at ensuring local and intra-bureaucratic support as determinants of policy design choices have produced a notable deviation from a set of commonly applied PES policy recommendations. The strong presence of ICDP-type components in the programs is also questionable with regard to cost-efficiency. Crucially, failure to account for heterogeneity in ecosystem service provision and opportunity costs in the design of payments leaves ample scope to the adverse self-selection of non-threatened forest areas into the program, allowing for several of the enrolled areas to generate sub-optimal conservation benefits in relation to the resources invested. Indeed, a preliminary study suggests that Socio Bosque "has provided little conservation additionality in terms of the prevented deforestation" [85] (p. 112); a more recent rigorous study showed the program to reduce deforestation by $1.5 \%$ in the areas that received the program's direct payments [101], while Börner et al. [102] show that Programa Bosques is designed suboptimally both in terms of conservation effectiveness and net benefit distribution. Additionally, an evaluation of the socioeconomic impacts of Programa Bosques shows that, despite the increase in the scale of production, there is no increase in the value of product sales by the beneficiaries, due to the low returns to investment and limited market articulation [103].

On the other hand, the environmental components of the programs also had more indirect positive outcomes. In Peru, the deforestation monitoring capacity has been strengthened through the activities of Programa Bosques [104,105]. Likewise, the program has improved the cooperation of MINAM with provincial governments on environmental issues. Socio Bosque has also helped to improve information on forests in the country, and the program became a blueprint for other environmental policies in the country (e.g., mangrove protection and biocommerce). Moreover, the changes in the payment structure of the program show a move towards an implicit recognition of opportunity costs as an element to improve the efficiency of the scheme.

Our findings are to some extent in line with the literature that highlights the importance of local contexts in REDD+ and PES [10,15,16,25,106]. Karsenty and Ongolo [9] discussed the difficulties of implementing REDD+ in "fragile states", and we showed that even in better-functioning democracies and administrations, political and bureaucratic constraints may get in the way of cost-efficient 
PES and REDD+ design. Despite the "globalist, homogenizing nature of REDD+ guidelines" [26] (p. 78), reviews on implementation show a patchwork of conceptualizations, guidelines, and forms of institutionalization [10,15,107]. However, we agree with Angelsen [4] (p. 238), that "the core idea of REDD+" remains "to apply conditionality and make payments to countries (and projects) based on performance or results". To prevent REDD+ from becoming simply the 'conservation fad' that some authors identify $[108,109]$, efficiency-oriented recommendations must remain central to what program designers, especially within the REDD+ policy mix, should strive for $[46,51]$, without losing sight of the potential equity risks [14].

The design of the programs has shown several politically and administratively sensitive issues that will be at the heart of the design of many 'multi-objective' REDD+ program. The active promotion of non-carbon benefits for REDD+ and PES means that any discussion on the design of programs will experience similar political repercussions and pressures as the ones we found in Socio Bosque and Programa Bosques. PES and REDD+ are marred with tradeoffs and risks [10,14,69], which will require explicit recognition and action [4]. Transparent priority setting in public policy, independent decision-making capabilities, funding for agencies responsible for REDD+ or PES programs, and sound technical provisions are jointly needed to ensure that the schemes efficiently generate emissions reductions.

It is likely that governments will remain the main promoters and funders for PES and REDD+ in the foreseeable future. Our findings help explain why the policy-making dynamics, such as intra-governmental conflicts and power imbalances between sectors and agencies, are key factors leading to the prevalence of multi-objective REDD+. It remains to be seen how governments will balance pressures for non-carbon benefits and equity considerations by ensuring the necessary cost-efficient emissions reductions, which will certainly be required for eligibility in future REDD+ funding schemes. Instead of reproducing an unrealistic "win-win ecological modernization discourse" [15] (p. 133), governments will likely better fulfill their REDD+ agendas by recognizing and addressing the political tradeoffs inherent to multi-objective REDD+.

It is clear from our findings that not enough emphasis is placed on adapting technical recommendations to the contexts in which they must be turned into real policies. Indeed, better knowledge of what constitutes a favorable public policy environment for effective REDD+ can help to avoid investments in doomed policy programs. Without doubt, for PES programs to be cost-effective REDD+ vehicles, intra-governmental conflicts and imbalances as well as the short-term planning horizons of politicians and bureaucrats, will have to be jointly addressed with technical challenges. Strategies to enhance program efficiency, therefore, should be based on a careful evaluation of context-specific political and institutional constraints, if both environmental and social objectives are to be reached.

Supplementary Materials: The following are available online at http:/ / www.mdpi.com/1999-4907/9/11/725/s1, Table S1: Targeting criteria of the Socio Bosque program; Table S2: Payment calculation examples for Socio Bosque, under the previous and current payment structure.

Author Contributions: H.R.d.C. and J.B. designed the study; H.R.d.C. collected and analyzed the data; H.R.d.C., J.B. and S.W. wrote the manuscript.

Funding: This research was funded by the Robert Bosch Foundation (grant 32.5.8043.0012.0), the German Federal Ministry for Economic Cooperation and Development (grant 81180343), Norad, and the European Commission (grant DCI-ENV/2011/269520). And the APC was funded by the German Federal Ministry for Economic Cooperation and Development (grant 81180343).

Acknowledgments: The helpful comments of the reviewers are appreciated and the remaining errors and omissions are responsibility of the authors.

Conflicts of Interest: The authors declare no conflicts of interest. 


\section{Appendix A. List of Respondents}

Ecuador

1. Foreign technical cooperation staff

2, 3, 4. Socio Bosque staff

5, 6. Former high-level Environment Ministry (MAE) decision makers

$7,8,9,10$. NGO technical cooperation staff

11. Local NGO staff

12. Environmental Policy specialist

13. Former high-level MAE decision maker

14. Environmental Policy specialist

\section{Peru}

15, 16. Foreign technical cooperation staff

17, 18, 19, 20, 21. Programa Bosques staff

22. Former Programa Bosques director

23. Former Programa Bosques staff

24. Former high-level MINAM decision maker

25. Former Programa Bosques staff

26. MEF staff

27. Social Development ministry staff

28. High-level MINAM decision maker

\section{References}

1. Pagiola, S. Using PES to Implement REDD; PES Learning Paper, 2011-1; World Bank: Washington, DC, USA, 2011.

2. FONAFIFO; CONAFOR; Ministry of Environment of Ecuador. Lessons Learned for REDD+ from PES and Conservation Incentive Programs. Examples from Costa Rica, Mexico, and Ecuador; World Bank: Washington, DC, USA, 2012.

3. Wunder, S. Can payments for environmental services reduce deforestation and forest degradation? In Realising REDD+: National Strategy and Policy Options; Angelsen, A., Brockhaus, M., Eds.; Center for International Forestry Research: Bogor, Indonesia, 2009; pp. 213-221.

4. Angelsen, A. REDD+ as Result-based Aid. General Lessons and Bilateral Agreements of Norway. Rev. Dev. Econ. 2017, 21, 237-264. [CrossRef]

5. Wunder, S.; Engel, S.; Pagiola, S. Taking stock. A comparative analysis of payments for environmental services programs in developed and developing countries. Ecol. Econ. 2008, 65, 834-852. [CrossRef]

6. Samii, C.; Lisiecki, M.; Kulkarni, P.; Paler, L.; Chavis, L. Effects of Payment for Environmental Services (PES) on Deforestation and Poverty in Low and Middle-Income Countries: A Systematic Review. Campbell Syst. Rev. 2014. [CrossRef]

7. Wunder, S. Payments for Environmental Services—Some Nuts and Bolts; Occasional Paper; CIFOR: Bogor, Indonesia, 2005.

8. Pattanayak, S.; Wunder, S.; Ferraro, P. Show Me the Money. Do Payments Supply Environmental Services in Developing Countries? Rev. Environ. Econ. Policy 2010, 4, 254-274. [CrossRef]

9. Karsenty, A.; Ongolo, S. Can "fragile states" decide to reduce their deforestation? The inappropriate use of the theory of incentives with respect to the REDD mechanism. For. Policy Econ. 2012, 18, 38-45. [CrossRef]

10. Brockhaus, M.; di Gregorio, M. National REDD+ policy networks. From cooperation to conflict. Ecol. Soc. 2014, 19, 14. [CrossRef]

11. Di Gregorio, M.; Brockhaus, M.; Cronin, T.; Muharrom, E.; Mardiah, S.; Santoso, L. Deadlock or Transformational Change? Exploring Public Discourse on REDD+ Across Seven Countries. Glob. Environ. Politics 2015, 15, 63-84. [CrossRef] 
12. Vijge, M.J.; Brockhaus, M.; di Gregorio, M.; Muharrom, E. Framing national REDD+ benefits, monitoring, governance and finance. A comparative analysis of seven countries. Glob. Environ. Chang. 2016, 39, 57-68. [CrossRef]

13. Brockhaus, M.; Korhonen-Kurki, K.; Sehring, J.; di Gregorio, M.; Assembe-Mvondo, S.; Babon, A.; Bekele, M.; Gebara, M.F.; Khatri, D.B.; Kambire, H.; et al. REDD+, transformational change and the promise of performance-based payments. A qualitative comparative analysis. Clim. Policy 2016, 17, 708-730. [CrossRef]

14. Loft, L.; Pham, T.T.; Wong, G.Y.; Brockhaus, M.; Le, D.N.; Tjajadi, J.S.; Luttrell, C. Risks to REDD+. Potential pitfalls for policy design and implementation. Environ. Conserv. 2017, 44, 44-55. [CrossRef]

15. Di Gregorio, M.; Gallemore, C.T.; Brockhaus, M.; Fatorelli, L.; Muharrom, E. How institutions and beliefs affect environmental discourse. Evidence from an eight-country survey on REDD+. Glob. Environ. Chang. 2017, 45, 133-150. [CrossRef]

16. Korhonen-Kurki, K.; Brockhaus, M.; Sehring, J.; di Gregorio, M.; Assembe-Mvondo, S.; Babon, A.; Bekele, M.; Benn, V.; Gebara, M.F.; Kambire, H.; et al. What drives policy change for REDD+? A qualitative comparative analysis of the interplay between institutional and policy arena factors. Clim. Policy 2018, 73, 1-14. [CrossRef]

17. Gallemore, C.; Di Gregorio, M.; Moeliono, M.; Brockhaus, M. Transaction costs, power, and multi-level forest governance in Indonesia. Ecol. Econ. 2015, 114, 168-179. [CrossRef]

18. Sunderlin, W.D.; Sills, E.O.; Duchelle, A.E.; Ekaputri, A.D.; Kweka, D.; Toniolo, M.A.; Ball, S.; Doggart, N.; Pratama, C.D.; Padilla, J.T.; et al. REDD+ at a critical juncture. Assessing the limits of polycentric governance for achieving climate change mitigation. Int. For. Rev. 2015, 17, 400-413. [CrossRef]

19. Gallemore, C. Transaction costs in the evolution of transnational polycentric governance. Int. Environ. Agreem. 2017, 17, 639-654. [CrossRef]

20. Rodriguez-Ward, D.; Larson, A.M.; Ruesta, H.G. Top-down, Bottom-up and Sideways. The Multilayered Complexities of Multi-level Actors Shaping Forest Governance and REDD+ Arrangements in Madre de Dios, Peru. Environ. Manag. 2018, 62, 98-116. [CrossRef] [PubMed]

21. Dunlop, T.; Corbera, E. Incentivizing REDD+. How developing countries are laying the groundwork for benefit-sharing. Environ. Sci. Policy 2016, 63, 44-54. [CrossRef]

22. Ochieng, R.M.; Arts, B.; Brockhaus, M.; Visseren-Hamakers, I.J. Institutionalization of REDD+ MRV in Indonesia, Peru, and Tanzania. Progress and implications. Ecol. Soc. 2018, 23, 8. [CrossRef]

23. Hrabanski, M.; Bidaud, C.; le Coq, J.; Méral, P. Environmental NGOs, policy entrepreneurs of market-based instruments for ecosystem services? A comparison of Costa Rica, Madagascar and France. For. Policy Econ. 2013, 37, 124-132. [CrossRef]

24. Le Coq, J.; Froger, G.; Pesche, D.; Legrand, T.; Saenz, F. Understanding the governance of the Payment for Environmental Services Programme in Costa Rica. A policy process perspective. Ecosyst. Serv. 2015, 16, 253-265. [CrossRef]

25. Pasgaard, M. Lost in translation? How project actors shape REDD+ policy and outcomes in Cambodia. Asia Pac. Viewp. 2015, 56, 111-127. [CrossRef]

26. Asiyanbi, A.; Arhin, A.; Isyaku, U. REDD+ in West Africa. Politics of Design and Implementation in Ghana and Nigeria. Forests 2017, 8, 78. [CrossRef]

27. Wibowo, A.; Giessen, L. Absolute and relative power gains among state agencies in forest-related land use politics. The Ministry of Forestry and its competitors in the REDD+ Programme and the One Map Policy in Indonesia. Land Use Policy 2015, 49, 131-141. [CrossRef]

28. McGregor, A.; Challies, E.; Howson, P.; Astuti, R.; Dixon, R.; Haalboom, B.; Gavin, M.; Tacconi, L.; Afiff, S. Beyond Carbon, More Than Forest? REDD+ Governmentality in Indonesia. Environ. Plan. A 2015, 47, 138-155. [CrossRef]

29. Rosa da Conceição, H.; Börner, J.; Wunder, S. Why were upscaled incentive programs for forest conservation adopted? Comparing policy choices in Brazil, Ecuador, and Peru. Ecosyst. Serv. 2015, 16, 243-252. [CrossRef]

30. Corbera, E.; Soberanis, C.G.; Brown, K. Institutional dimensions of Payments for Ecosystem Services. An analysis of Mexico's carbon forestry programme. Ecol. Econ. 2009, 68, 743-761. [CrossRef]

31. Vatn, A. An institutional analysis of payments for environmental services. Ecol. Econ. 2010, 69, 1245-1252. [CrossRef]

32. Hausknost, D.; Grima, N.; Singh, S.J. The political dimensions of Payments for Ecosystem Services (PES). Cascade or stairway? Ecol. Econ. 2017, 131, 109-118. [CrossRef] 
33. Ostrom, E. Institutional Rational Choice. In Theories of the Policy Process; Paul, S., Ed.; Westview Press: Boulder, CO, USA, 2007.

34. Howlett, M. Governance Modes, Policy Regimes and Operational Plans. A Multi-Level Nested Model of Policy Instrument Choice and Policy Design. Policy Sci. 2009, 42, 73-89. [CrossRef]

35. Baumol, W.; Oates, W. The Theory of Environmental Policy; Cambridge University Press: Cambridge, UK, 1988.

36. Keohane, N.; Revesz, R.; Stavins, R. The Choice of Regulatory Instruments in Environmental Policy. Harv. Environ. Law Rev. 1998, 22, 313-367.

37. Aidt, T. Political Internalization of Economic Externalities and Environmental Policy. J. Public Econ. 1998, 69, 1-16. [CrossRef]

38. Lipsky, M. Street-Level Bureaucracy. Dilemmas of the Individual in Public Services-30th Anniversary Expanded Edition; Russel Sage Foundation: New York, NY, USA, 2010.

39. Kingdon, J. Agendas, Alternatives, and Public Policies; Little, Brown: Boston, MA, USA, 1984.

40. Webber, D. Analyzing Political Feasibility. Political Scientists' Unique Contribution to Policy Analysis. Policy Stud. J. 1986, 14, 545-553. [CrossRef]

41. Linder, S.; Peters, G. Instruments of Government. Perceptions and Contexts. J. Public Policy 1989, 9, 35-58. [CrossRef]

42. Dan Wood, B.; Waterman, R.W. Bureaucratic Dynamics. The Role of Bureaucracy in a Democracy; Westview Press: Boulder, CO, USA, 1994.

43. Cox, G.; McCubbins, M. The Institutional Determinants of Economic Policy Outcomes. In Structure and Policy in Presidential Democracies; Haggard, S., McCubbins, M., Eds.; Cambridge University Press: New York, NY, USA, 2001.

44. Rose, R. What Is Lesson-Drawing? J. Public Policy 1991, 11, 3-30. [CrossRef]

45. Dolowitz, D.; Marsh, D. Learning from Abroad. The Role of Policy Transfer in Contemporary Policy-Making. Governance 2000, 13, 5-24. [CrossRef]

46. Wunder, S.; Brouwer, R.; Engel, S.; Ezzine-de-Blas, D.; Muradian, R.; Pascual, U.; Pinto, R. From principles to practice in paying for nature's services. Nat. Sustain. 2018, 1, 145-150. [CrossRef]

47. Wunder, S. The efficiency of payments for environmental services in tropical conservation. Conserv. Boil. 2007, 21, 48-58. [CrossRef] [PubMed]

48. Engel, S.; Pagiola, S.; Wunder, S. Designing payments for environmental services in theory and practice. An overview of the issues. Ecol. Econ. 2008, 65, 663-674. [CrossRef]

49. Honey-Rosés, J.; López-García, J.; Rendón-Salinas, E.; Peralta-Higuera, A.; Galindo-Leal, C. To pay or not to pay? Monitoring performance and enforcing conditionality when paying for forest conservation in Mexico. Environ. Conserv. 2009, 36, 120-128. [CrossRef]

50. Ferraro, P.; Pattanayak, S. Money for nothing? A call for empirical evaluation of biodiversity conservation investments. PLoS Boil. 2006, 4, e105. [CrossRef] [PubMed]

51. Engel, S. The Devil in the Detail-A Practical Guide on Designing Payments for Environmental Services. IRERE 2016, 9, 131-177. [CrossRef]

52. Pagiola, S.; Arcenas, A.; Platais, G. Can Payments for Environmental Services Help Reduce Poverty? An Exploration of the Issues and the Evidence to Date from Latin America. World Dev. 2005, 33, 237-253. [CrossRef]

53. Wunder, S. Payments for environmental services and the poor: Concepts and preliminary evidence. Environ. Dev. Econ. 2008, 13, 279-297. [CrossRef]

54. Grieg-Gran, M.; Porras, I.; Wunder, S. How Can Market Mechanisms for Forest Environmental Services Help the Poor? Preliminary Lessons from Latin America. World Dev. 2005, 33, 1511-1527. [CrossRef]

55. Wünscher, T.; Engel, S.; Wunder, S. Spatial targeting of payments for environmental services. A tool for boosting conservation benefits. Ecol. Econ. 2008, 65, 822-833. [CrossRef]

56. Alix-Garcia, J.; Janvry, A.D.; Sadoulet, E. The role of deforestation risk and calibrated compensation in designing payments for environmental services. Environ. Dev. Econ. 2008, 13, 375-394. [CrossRef]

57. Chen, X.; Lupi, F.; Vina, A.; He, G.; Liu, J. Using cost-effective targeting to enhance the efficiency of conservation investments in payments for ecosystem services. Conserv. Boil. 2010, 24, 1469-1478. [CrossRef] [PubMed]

58. Wätzold, F.; Dreschler, M. Spatially Uniform versus Spatially Heterogeneous Compensation Payments for Biodiversity-Enhancing Land-Use Measures. Environ. Resour. Econ. 2005, 31, 73-93. [CrossRef] 
59. Ferraro, P.J. Asymmetric information and contract design for payments for environmental services. Ecol. Econ. 2008, 65, 810-821. [CrossRef]

60. Ferraro, P.; Kiss, A. Direct Payments to Conserve Biodiversity. Science 2002, 298, 1718-1719. [CrossRef] [PubMed]

61. Ferraro, P. Global Habitat Protection. Limitations of Development Interventions and a Role for Conservation Performance Payments. Conserv. Biol. 2001, 15, 990-1000. [CrossRef]

62. Ferraro, P.; Simpson, R.D. The Cost-Effectiveness of Conservation Payments. Land Econ. 2002, 78, 339-353. [CrossRef]

63. MAE (Ministerio del Ambiente). Reporte de Gestión del Monitoreo de Cobertura Vegetal del Programa Socio Bosque; MAE Ministerio del Ambiente: Quito, Ecuador, 2015.

64. MAE (Ministerio del Ambiente). Línea Base de Deforestación del Ecuador Continental; Ministerio del Ambiente: Quito, Ecuador, 2012.

65. MINAM (Ministerio del Ambiente). Directiva No. 001-2017-MINAM/VMDERN/PNCB-Suscripción, Ratificación, Supensión, Resolución y Liquidación de Convenios para la Conservación de Bosques; MINAM: Lima, Peru, 2017.

66. Acosta, A.; Araujo, M.C.; Perez-Liñan, A.; Saiegh, S. Jugadores de veto, instituciones volubles y politicas de baja calidad: El juego politico en Ecuador. In El Juego Político en América Latina: ¿Cómo se Deciden las Políticas Públicas? Scartascini, C., Spiller, P., Stein, E., Tommasi, M., Eds.; BID: Bogotá, Colombia, 2010.

67. Andrade, P. Unfinished Business: State-Building and Large-Scale Mining under the Citizen's Revolution in Ecuador; ENGOV Working Paper Series; ENGOV: Quito, Ecuador, 2013.

68. Melendez, C.; Leon, C. Perú 2009_Los Legados del Autoritarismo. Rev. De Cienc. Política 2010, 30, $451-477$. [CrossRef]

69. Muradian, R.; Arsel, M.; Pellegrini, L.; Adaman, F.; Aguilar, B.; Agarwal, B.; Corbera, E.; Ezzine de Blas, D.; Farley, J.; Froger, G.; et al. Payments for ecosystem services and the fatal attraction of win-win solutions. Conserv. Lett. 2013, 6, 274-279. [CrossRef]

70. Pascual, U.; Phelps, J.; Garmendia, E.; Brown, K.; Corbera, E.; Martin, A.; Gomez-Baggethun, E.; Muradian, R. Social Equity Matters in Payments for Ecosystem Services. BioScience 2014, 64, 1027-1036. [CrossRef]

71. Greiner, R.; Stanley, O. More than money for conservation. Exploring social co-benefits from PES schemes. Land Use Policy 2013, 31, 4-10. [CrossRef]

72. de Koning, F.; Aguiñaga, M.; Bravo, M.; Chiu, M.; Lascano, M.; Lozada, T.; Suarez, L. Bridging the gap between forest conservation and poverty alleviation. The Ecuadorian Socio Bosque program. Environ. Sci. Policy 2011, 14, 531-542. [CrossRef]

73. Fehse, J. Private Conservation Agreements Support Climate Action: Ecuador's Socio Bosque programme (Inside Stories on Climate Compatible Development); CDKN: Cape Town, South Africa, 2012.

74. Krause, T.; Collen, W.; Nicholas, K. Evaluating safeguards in a conservation incentive program. Participation, consent, and benefit sharing in indigenous communities of the Ecuadorian Amazon. Ecol. Soc. 2013, 18, 1. [CrossRef]

75. Seligson, M. The Rise of Populism and the Left in Latin America. J. Democr. 2007, 18, 81-95. [CrossRef]

76. Remmer, K. The Rise of Leftist- Populist Governance in Latin America. The Roots of Electoral Change. Comp. Political Stud. 2012, 45, 947-972. [CrossRef]

77. Hunter, W.; Power, T. Rewarding Lula. Executive Power, Social Policy, and the Brazilian Elections of 2006. Lat. Am. Politics Soc. 2007, 49, 1-30. [CrossRef]

78. Layton, M.; Smith, A.E. Incorporating Marginal Citizens and Voters. The Conditional Electoral Effects of Targeted Social Assistance in Latin America. Comp. Political Stud. 2015, 48, 854-881. [CrossRef]

79. Sewall, R. Conditional Cash Transfer Programs in Latin America. SAIS Rev. Int. Aff. 2008, 28, $175-187$. [CrossRef]

80. Zucco, C. When Payouts Pay off. Conditional Cash Transfers and Voting Behavior in Brazil 2002-10. Am. J. Political Sci. 2013, 57, 810-822. [CrossRef]

81. Baud, M.; de Castro, F.; Hogenboom, B. Environmental Governance in Latin America. Towards an Integrative Research Agenda. Eur. Rev. Lat. Am. Caribb. Stud. 2011, 90, 79-88. [CrossRef]

82. Confederação Nacional da Indústria (CNI). Pesquisa CNI-IBOPE: Retratos da Sociedade Brasileira: Meio Ambiente; CNI: Brasília, Brazil, 2012.

83. IPSOS. Perspectivas Electorales y Preocupaciones Ciudadanas; IPSOS: Lima, Peru, 2014. 
84. Wünscher, T.; Engel, S. International payments for biodiversity services. Review and evaluation of conservation targeting approaches. Boil. Conserv. 2012, 152, 222-230. [CrossRef]

85. Mohebalian, P.; Aguilar, F. Additionality and design of forest conservation programs: Insights from Ecuador's Socio Bosque Program. For. Policy Econ. 2016, 71, 103-114. [CrossRef]

86. MAE (Ministerio del Ambiente). Manual Operativo Unificado 2012 Proyecto Socio Bosque; Ministerio del Ambiente: Quito, Ecuador, 2012.

87. Holland, M.; de Koning, F.; Morales, M.; Naughton-Treves, L.; Robinson, B.; Suárez, L. Complex Tenure and Deforestation. Implications for Conservation Incentives in the Ecuadorian Amazon. World Dev. 2014, 55, 21-36. [CrossRef]

88. MINAM (Ministerio del Ambiente). Manual de Operaciones del Programa Nacional de Conservación de Bosques para la Mitigación del Cambio Climático; MINAM: Lima, Peru, 2013.

89. Persson, M.; Alpízar, F. Conditional Cash Transfers and Payments for Environmental Services-A Conceptual Framework for Explaining and Judging Differences in Outcomes. World Dev. 2013, 43, 124-137. [CrossRef]

90. Alix-Garcia, J.M.; Sims, K.R.E.; Yañez-Pagans, P. Only One Tree from Each Seed? Environmental Effectiveness and Poverty Alleviation in Mexico's Payments for Ecosystem Services Program. Am. Econ. J. Econ. Policy 2015, 7, 1-40. [CrossRef]

91. Profafor, S.A.; GIZ. Diseño de un Proyecto REDD+ en Comunas Kichwas de la Amazonia Ecuatoriana; Serie Sistematización No. 8; GIZ: Quito, Ecuador, 2013.

92. Bremer, L.L.; Farley, K.A.; Lopez-Carr, D. What factors influence participation in payment for ecosystem services programs? An evaluation of Ecuador's SocioPáramo program. Land Use Policy 2014, 36, 122-133. [CrossRef]

93. Jones, K.W.; Holland, M.B.; Naughton-Treves, L.; Morales, M.; Suarez, L.; Keenan, K. Forest conservation incentives and deforestation in the Ecuadorian Amazon. Environ. Conserv. 2016. [CrossRef]

94. Ezzine-de-Blas, D.; Wunder, S.; Ruiz-Pérez, M.; Moreno-Sanchez, R.D. Global Patterns in the Implementation of Payments for Environmental Services. PLoS ONE 2016, 11, e0149847. [CrossRef] [PubMed]

95. Krause, T.; Loft, L. Benefit Distribution and Equity in Ecuador's Socio Bosque Program. Soc. Nat. Resour. 2013, 26, 1170-1184. [CrossRef]

96. Ministerio del Ambiente (MAE). Manual Operativo del Proyecto Socio Bosque; MAE: Quito, Ecuador, 2009.

97. Ministerio del Ambiente (MAE). Acuerdo Ministerial No 130; MAE: Quito, Ecuador, 2011.

98. Lambin, E.; Meyfroidt, P.; Rueda, X.; Blackman, A.; Börner, J.; Cerutti, P.; Dietsch, T.; Jungmann, L.; Lamarque, P.; Lister, J.; et al. Effectiveness and synergies of policy instruments for land use governance in tropical regions. Glob. Environ. Chang. 2014, 28, 129-140. [CrossRef]

99. Simpson, R.D.; Sedjo, R. Paying for the conservation of endangered ecosystems. A comparison of direct and indirect approaches. Environ. Dev. Econ. 1996, 1, 241-257. [CrossRef]

100. Collen, W.; Krause, T.; Mundaca, L.; Nicholas, K.A. Building local institutions for national conservation programs: Lessons for developing Reducing Emissions from Deforestation and Forest Degradation (REDD+) programs. Ecol. Soc. 2016, 21, 4. [CrossRef]

101. Cuenca, P.; Robalino, J.; Arriagada, R.; Echeverría, C. Are government incentives effective for avoided deforestation in the tropical Andean forest? PLoS ONE 2018, 13, e0203545. [CrossRef] [PubMed]

102. Börner, J.; Wunder, S.; Giudice, R. Will up-scaled forest conservation incentives in the Peruvian Amazon produce cost-effective and equitable outcomes? Environ. Conserv. 2016, 43, 407-416. [CrossRef]

103. Euler, M. Efectos Socio-Económicos de las Transferencias Directas Condicionadas en las Comunidades Nativas Beneficiarias del Programa Bosques; GIZ: Lima, Peru, 2016.

104. Ochieng, R.M.; Visseren-Hamakers, I.J.; Brockhaus, M.; Kowler, L.F.; Herold, M.; Arts, B. Historical development of institutional arrangements for forest monitoring and REDD + MRV in Peru. Discursiveinstitutionalist perspectives. For. Policy Econ. 2016, 71, 52-59. [CrossRef]

105. Robiglio, V.; Armas, A.D.; Silva Aguad, C.; White, D. Beyond REDD+ readiness. Land-use governance to reduce deforestation in Peru. Clim. Policy 2014, 14, 734-747. [CrossRef]

106. Jespersen, K.; Gallemore, C. “The Institutional Work of Payments for Ecosystem Services: Why the Mundane Should Matter". Ecol. Econ. 2018, 146, 507-519. [CrossRef]

107. Turnhout, E.; Gupta, A.; Weatherley-Singh, J.; Vijge, M.J.; de Koning, J.; Visseren-Hamakers, I.J.; Herold, M.; Lederer, M. Envisioning REDD+ in a post-Paris era. Between evolving expectations and current practice. WIREs Clim. Chang. 2017. [CrossRef] 
108. Lund, J.F.; Sungusia, E.; Mabele, M.B.; Scheba, A. Promising Change, Delivering Continuity. REDD+ as Conservation Fad. World Dev. 2017, 89, 124-139. [CrossRef]

109. Redford, K.H.; Padoch, C.; Sunderland, T. Fads, funding, and forgetting in three decades of conservation. Conserv. Boil. 2013, 27, 437-438. [CrossRef] [PubMed] 